\title{
Activation of microglial cells triggers a release of brain-derived neurotrophic factor (BDNF) inducing their proliferation in an adenosine $A_{2 A}$ receptor-dependent manner: $A_{2 A}$ receptor blockade prevents $B D N F$ release and proliferation of microglia
}

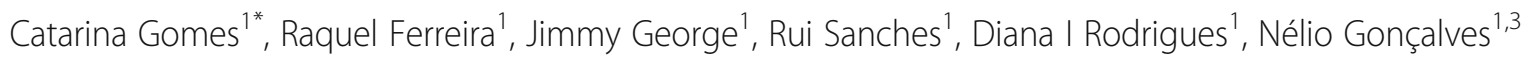
and Rodrigo A Cunha ${ }^{1,2}$

\begin{abstract}
Background: Brain-derived neurotrophic factor (BDNF) has been shown to control microglial responses in neuropathic pain. Since adenosine $A_{2 A}$ receptors $\left(A_{2 A} R s\right)$ control neuroinflammation, as well as the production and function of BDNF, we tested to see if $A_{2 A} R$ controls the microglia-dependent secretion of BDNF and the proliferation of microglial cells, a crucial event in neuroinflammation.
\end{abstract}

Methods: Murine N9 microglial cells were challenged with lipopolysaccharide (LPS, $100 \mathrm{ng} / \mathrm{mL}$ ) in the absence or in the presence of the $A_{2 A} R$ antagonist, SCH58261 (50 nM), as well as other modulators of $A_{2 A} R$ signaling. The BDNF cellular content and secretion were quantified by Western blotting and ELISA, $A_{2 A} R$ density was probed by Western blotting and immunocytochemistry and cell proliferation was assessed by BrdU incorporation. Additionally, the $A_{2 A} R$ modulation of LPS-driven cell proliferation was also tested in primary cultures of mouse microglia.

Results: LPS induced time-dependent changes of the intra- and extracellular levels of BDNF and increased microglial proliferation. The maximal LPS-induced BDNF release was time-coincident with an LPS-induced increase of the $A_{2 A} R$ density. Notably, removing endogenous extracellular adenosine or blocking $A_{2 A} R$ prevented the LPS-mediated increase of both BDNF secretion and proliferation, as well as exogenous BDNF-induced proliferation. Conclusions: We conclude that $A_{2 A} R$ activation plays a mandatory role controlling the release of BDNF from activated microglia, as well as the autocrine/paracrine proliferative role of BDNF.

Keywords: Adenosine $A_{2 A}$ receptors, Neuroinflammation, Microglia, BDNF

\footnotetext{
* Correspondence: catarinareisvalegomes@gmail.com

${ }^{1}$ Center for Neuroscience and Cell Biology, University of Coimbra, Largo

Marquês de Pombal, Coimbra 3004-517, Portugal

Full list of author information is available at the end of the article
} 


\section{Background}

Neurodegenerative pathologies, such as Alzheimer's or Parkinson's disease, progress with a sustained, chronic neuroinflammatory process [1,2]. Microglial cells, which display specialized immune functions in the central nervous system, play a crucial role in neuroinflammation $[2,3]$, undergoing a process globally known as microgliosis. Microgliosis encompasses morphological changes, cell proliferation and modifications in the synthesis and secretion of both pro- and anti-inflammatory substances [4], whose temporal balance determines the contention or the perpetuation of neuroinflammation. Thus, neuroinflammation is a tightly regulated process involving several modulators, including adenosine [5]. The relation between adenosine and neuroinflammation is heralded by the key role of adenosine $A_{2 A}$ receptors $\left(A_{2 A} R\right)$ in peripheral inflammation [6], as well as by the localization of $\mathrm{A}_{2 \mathrm{~A}} \mathrm{R}$ in microglial cells and the ability of $\mathrm{A}_{2 \mathrm{~A}} \mathrm{R}$ to control several microglial functions, namely chemotaxis [7] and the production of inflammatory mediators $[8,9]$.

One of the most notable modulatory properties of adenosine is the ability of $\mathrm{A}_{2 \mathrm{~A}} \mathrm{R}$ activation to potentiate the production, secretion and effects of different trophic factors [10]. This effect has been considered neuroprotective, in accordance with the ability of trophic factors to prevent neuronal damage or to promote neuronal repair [11-13]. However, it seems to contradict the welldescribed neuroprotective role mediated by $\mathrm{A}_{2 \mathrm{~A}} \mathrm{R}$ antagonism [14,15]. BDNF (brain-derived neurotrophic factor), which is mostly recognized as a pro-survival factor, has also been shown to support microglial activation in vivo [16]. This could result in a potential amplification of microgliosis and neuroinflammation, as occurs in neuropathic pain $[17,18]$, with BDNF release resulting either through neuronal activity-dependent exocytosis or from microglia using an exocytotic pathway or a constitutive release pathway present in all cell types (reviewed in [19]), both of which are prone to modulation [20,21]. Therefore, BDNF emerges as a potential candidate for mediating the switch between acute neuroinflammation (which is beneficial in resolving brain-noxious stimuli) and chronic neuroinflammation, which is thought to be a main player in the progression of neurodegenerative diseases [2].

To date, it has not been explored whether $\mathrm{A}_{2 \mathrm{~A}} \mathrm{R}$ controls microglial levels of neurotrophic factors or its involvement in autocrine/paracrine actions potentially sustaining microgliosis over time. Thus, this study was designed to test whether the $\mathrm{A}_{2 \mathrm{~A}} \mathrm{R}$ blockade modulates BDNF secretion and microglial proliferation induced by the inflammatory trigger lipopolysaccharide (LPS), which would indicate that $\mathrm{A}_{2 \mathrm{~A}} \mathrm{R}$ acts as a key controller of microglial function and neuroinflammation.

\section{Methods}

\section{Cell line and primary microglial cultures}

A murine microglial cell line, N9 (a kind gift from Professor Claudia Verderio, CNR Institute of Neuroscience, Cellular and Molecular Pharmacology, Milan, Italy), was grown in an RPMI medium supplemented with $30 \mathrm{mM}$ glucose (Sigma, Sintra, Portugal), $100 \mathrm{U} / \mathrm{mL}$ penicillin and $100 \mu \mathrm{g} / \mathrm{mL}$ streptomycin (GIBCO, Invitrogen, Porto, Portugal).

Primary microglial cultures were prepared as previously described [22]. Briefly, primary cultures of glial cells were obtained from a postnatal (P1-P5) C57BL6 mouse and maintained for 15 days in the DMEM-F12 medium with glutamax (Invitrogen) containing 10\% fetal bovine serum (Invitrogen), 0.25\% gentamycin (Invitrogen) and $0.25 \mathrm{ng} / \mathrm{mL}$ M-CSF (murine-colony stimulating factor, Peprotech, Rocky Hill, New Jersey, USA). Microglia were then separated from the mixed primary culture by shaking $(200 \mathrm{rpm}$ for 2 hours), and plated in the DMEM-F12 medium with glutamax containing $0.25 \%$ gentamycin (Invitrogen).

Cells were kept at $37^{\circ} \mathrm{C}$ under a humidified atmosphere with $95 \% \mathrm{O}_{2}$ and $5 \% \mathrm{CO}_{2}$. Viable cells (identified by counting trypan-blue-excluding cellular elements) were plated at a density of $5 \times 10^{5}$ cells per $\mathrm{cm}^{2}$ in 6 well trays for Western blotting and enzyme-linked immunosorbent assay (ELISA) or $1 \times 10^{5}$ cells per $\mathrm{cm}^{2}$ in 12 well trays for proliferation and immunocytochemistry studies.

\section{Microglial cell pharmacological treatment}

In order to evaluate the ability of an inflammatory trigger to control the cellular content of BDNF over time, N9 cells were challenged with $100 \mathrm{ng} / \mathrm{mL}$ LPS (from Escherichia coli, serotype 055:B5 from Sigma) for 3, 6 and 12 hours. This concentration of LPS was chosen since it was previously shown to induce changes of $\mathrm{A}_{2 \mathrm{~A}} \mathrm{R}$ density in microglial cells [23], which we now aim to pharmacologically manipulate to modulate BDNF secretion/function. Thus, microglial cells were pre-incubated (20 minutes before LPS) with a supra-maximal and selective concentration (50 nM) of an $\mathrm{A}_{2 \mathrm{~A}} \mathrm{R}$ antagonist, SCH58261 [24], which was present until the end of the experiment $(3,6$ or 12 hours). Given that we were able to identify the tipping time point of the changes in BDNF levels and $\mathrm{A}_{2 \mathrm{~A}} \mathrm{R}$ modulation effects, subsequent experiments were carried out at this time point ( 6 hours). In all these experiments, 20 to 30 minutes before adding LPS, N9 cells were incubated with different modulators used in supra-maximal and selective concentrations gauged from our previous experience in different preparations [25,26]: adenosine deaminase (ADA, 1 $\mathrm{U} / \mathrm{mL}$, which removes endogenous adenosine; Sigma), H89 ( $1 \mu \mathrm{M}$, a protein kinase A (PKA) inhibitor; Tocris, Madrid, Spain), chelerythrine $(6 \mu \mathrm{M}$, a protein kinase $\mathrm{C}(\mathrm{PKC})$ inhibitor; Calbiochem, Lisbon, Portugal), or anti-human BDNF polyclonal antibody $(10 \mu \mathrm{g} / \mathrm{mL}$; Promega, Lisbon, Portugal), a concentration chosen according to [27]. ADA 
and the anti-human BDNF polyclonal antibody were directly diluted in the culture medium; H89 and chelerythrine were made up to a $25 \mathrm{mM}$ stock solution in water to dilute in the culture medium.

In the experiments carried out in the absence of LPS, N9 cells were incubated with PKA upstream modulators used in concentrations gauged from our previous experience in different preparations (for example [25,26]), namely: CGS21680 (30 nM; Sigma), an $\mathrm{A}_{2 \mathrm{~A}} \mathrm{R}$ selective agonist; forskolin (1 $\mu \mathrm{M}$; Ascent Scientific, Cambridge, UK), an activator of adenylate cyclase; 8-Br-AMP ( $5 \mu \mathrm{M}$; Tocris), a cyclic AMP (cAMP) analog, or with exogenously added BDNF (Sigma) used in a concentration $(20 \mathrm{ng} / \mathrm{mL})$ able to modulate $\mathrm{A}_{2 \mathrm{~A}} \mathrm{R}$-mediated neuronal functions [28]. BDNF was directly diluted in the culture medium, whereas CGS21680 and forskolin were made up in dimethyl sulfoxide (100 $\mathrm{mM})$ and 8-Br-AMP was made up in water $(100 \mathrm{mM})$ to dilute in the culture medium. We always tested the impact of the vehicles of the drugs and modulators on each measure and found that all the used vehicles were devoid of effects (data not shown).

\section{Western blotting}

Cell lysates were obtained in a lysis solution containing $150 \mathrm{mM} \mathrm{NaCl}, 50 \mathrm{mM}$ Tris-HCl, $1 \mathrm{mM}$ ethylenediamine tetraacetic acid (EDTA), 1\% NP-40 Igepal (Sigma, Sintra, Portugal), $0.1 \%$ sodium dodecyl sulfate (SDS), $0.5 \%$ sodium deoxycolate, $1 \mathrm{mM}$ (phenylmethylsulfonyl fluoride (PMSF), $1 \mathrm{mM}$ sodium ortovanadate, $1 \mathrm{mM} \mathrm{NaF}, 1 \mu \mathrm{g} / \mathrm{mL}$ CLAP (protease inhibitor cocktail; Sigma). After cell scraping for homogenization, the total amount of protein was quantified using the bicinchoninic acid (BCA; Thermo Scientific, Loures, Portugal) method. Samples were then loaded onto gels with $7.5 \%$ (to detect $\mathrm{A}_{2 \mathrm{~A}} \mathrm{R}, 50 \mathrm{kDa}$ and pro-BDNF, $37.5 \mathrm{kDa}$ ) or $15 \%$ (to detect mBDNF, $13 \mathrm{kDa}$ ) of acrylamide plus bisacrylamide (BioRad, Amadora, Portugal); proteins were separated by electrophoresis (100 to $120 \mathrm{~V}$ for 1 hour) using a bicine-buffered solution (20 mM Tris, $192 \mathrm{mM}$ bicine and 0.1\% SDS, pH 8.3) and then transferred $\left(300 \mathrm{mV}, 100\right.$ minutes, $\left.4^{\circ} \mathrm{C}\right)$ to polyvinylidene difluoride (PVDF) membranes $(0.45 \mu \mathrm{m}$ pore diameter) (GE Healthcare, Little Chalfont, Buckinghamshire, UK). Blots were then blocked for 1 hour at room temperature (RT) with 5\% low-fat milk in Tris-buffered saline (20 mM Tris, $140 \mathrm{mM} \mathrm{NaCl}, \mathrm{pH} 7.6$, TBS) with $0.1 \%$ Tween 20 (TBS-T) and incubated overnight at $4^{\circ} \mathrm{C}$ with primary antibodies diluted in TBS-T with $0.5 \%$ low-fat milk. The tested primary antibodies were mouse monoclonal anti-BDNF (1:1000; Sigma) and mouse anti- $\mathrm{A}_{2 \mathrm{~A}} \mathrm{R}$ (1:1000; Millipore, Lisbon, Portugal). After rinsing three times with $0.5 \%$ low-fat milk in TBS-T, membranes were incubated for 1 hour at RT with alkaline phosphataseconjugated secondary antibodies (1:2000; Amersham, Piscataway, New Jersey, USA). Protein immunoreactive bands were visualized in a Versa Doc Imaging System (Model 3000, BioRad Laboratories), after the incubation of the membrane with enhanced chemofluorescence reagent (ECF; GE Healthcare).

Re-probing of the same membranes with a different antibody was achieved by washing the ECF in $40 \%$ methanol for 30 minutes and stripping the previous antibodies in a solution of $0.2 \mathrm{M}$ glycine with $0.1 \%$ SDS and $1 \%(\mathrm{v} / \mathrm{v})$ Tween 20, pH 2.2, for 1 hour. After washing (3 times with TBS-T for 20 minutes), membranes were blocked and incubated with primary and respective secondary antibodies, namely for mouse anti- $\alpha$-tubulin (1:20000; Sigma) to confirm that similar amounts of sample were loaded to the different lanes.

\section{Immunocytochemistry}

Cells were fixed with $4 \%$ paraformaldehyde (Sigma) and permeabilized for 20 minutes in $0.25 \%$ Triton X-100 (Sigma) in a phosphate-buffered saline (PBS) solution $\left(137 \mathrm{mM} \mathrm{NaCl}, 2.7 \mathrm{mM} \mathrm{KCl}, 10 \mathrm{mM} \mathrm{NaH} \mathrm{PO}_{4}, 1.8 \mathrm{mM}\right.$ $\mathrm{KH}_{2} \mathrm{PO}_{4}, \mathrm{pH}$ 7.4). Unspecific binding was prevented by incubating cells in PBS with $3 \%$ bovine serum albumin (BSA) and 5\% normal horse serum. Cells were incubated overnight at $4{ }^{\circ} \mathrm{C}$ in PBS with 3\% BSA and 5\% normal horse serum and including the primary antibody (mouse anti- $\mathrm{A}_{2 \mathrm{~A}}, 1: 250$; Millipore). Cells were then washed and incubated for 1 hour at RT with an Alexa Fluor 488 donkey anti-mouse (1:400; Molecular Probes, Lisbon, Portugal) secondary antibody. Membrane ruffling, which is characteristic of activated microglia, was probed using a marker for filamentous actin, phalloidin, by incubating cells for 20 minutes at RT with PBS containing actin-stain 670 fluorescent phalloidin (1:75; Cytoskeleton, Denver, USA). For nuclear labeling, N9 cells were stained with DAPI (0.1 $\mathrm{mg} / \mathrm{mL}$; Invitrogen). The coverslips were mounted in the Prolong Gold Antifade fluorescent medium (Invitrogen). In order to check for non-specific labeling of the secondary antibodies or cross-reactivity between secondary antibodies, staining was tested in the absence of each primary antibody and in the absence of both primary antibodies. Fluorescent images were acquired using a Zeiss Imager Z2 fluorescence microscope equipped with an AxioCam HRm and 63x Plan-ApoChromat oil objective (1.4 numerical aperture), with Axiovision SE64 4.8.2 software. Ten images were randomly taken from each coverslip (three per condition in each experiment).

\section{BrdU incorporation assay}

Microglial proliferation was evaluated by measuring the incorporation of 5-bromo-2'-deoxyuridine (BrdU; Sigma), a synthetic nucleoside that can be incorporated into newly synthesized DNA, replacing thymidine during cell replication. Cells were incubated with BrdU $(10 \mu \mathrm{M})$ for the last 2 hours of pharmacological treatment, fixed in $4 \%$ 
paraformaldehyde, washed in TBS with $0.3 \%$ Triton X-100 and maintained in $1 \mathrm{M} \mathrm{HCl}$ at $37^{\circ} \mathrm{C}$ for 30 minutes. Nonspecific binding was prevented by incubation for 1 hour in TBS with 3\% BSA and 1\% Triton X-100. Cells were incubated overnight at $4^{\circ} \mathrm{C}$ with a primary rat antibody antiBrdU (1:100; Serotec, Oxford, UK) in a 0.1\% Triton X-100 and $0.3 \%$ BSA solution, washed and incubated for 2 hours at RT with an Alexa Fluor 594 donkey anti-rat secondary antibody (1:200; Molecular Probes). For nuclear staining, cells were incubated for 5 minutes at RT with Hoechst $33342(10 \mu \mathrm{g} / \mathrm{mL}$; Molecular Probes) in 0.3\% BSA, and mounted in Dakocytomation fluorescent medium (Dakocytomation Inc., California, USA). Fluorescent images were acquired using an Axioskop 2 Plus fluorescence microscope (Zeiss, PG-Hitec, Lisbon, Portugal). The number of proliferating cells (BrdU-positive) was counted and expressed as a percentage of the total cells stained with Hoechst 33342 [29].

\section{BDNF enzyme-linked immunosorbent assay}

The extracellular levels of BDNF were measured in the supernatant of N9 cells using the BDNF Emax Immunoassay System (Promega, Madison, USA). Each well of a 96well polystyrene plate was incubated overnight at $4^{\circ} \mathrm{C}$ with $80 \mu \mathrm{L}$ of anti-BDNF monoclonal antibody (1:1000) in coating carbonate buffer $(50 \mathrm{mM}, \mathrm{pH}$ 9.7). Non-adsorbed antibody was discarded and rinsed off by washing once in a TBS-T buffer (20 mM Tris-HCl, pH 7.6, $150 \mathrm{mM} \mathrm{NaCl}$ and $0.05 \%(\mathrm{v} / \mathrm{v})$ Tween 20$)$. Unspecific binding was prevented by blocking with $80 \mu \mathrm{L}$ Promega 1x Block and Sample Buffer (BB 1x) for 1 hour at RT. Plates were then washed (as mentioned before) and $80 \mu \mathrm{L}$ of each sample or standard ( $7.8 \mathrm{pg} / \mathrm{mL}$ to $500 \mathrm{pg} / \mathrm{mL}$ ) were loaded in triplicate to the plates (2 hours with $300 \mathrm{rpm}$ shaking at RT). After washing (5 times in TBS-T wash buffer), $80 \mu \mathrm{L}$ of anti-human BDNF polyclonal antibody (1:500 in BB 1x) was added to each well and the plates were incubated at RT (2 hours with $300 \mathrm{rpm}$ shaking). After washing (5 times in TBS-T wash buffer), the plates were incubated for 1 hour with shaking $(300 \mathrm{rpm})$ with $80 \mu \mathrm{L}$ anti-IgY horseradish peroxidase conjugate (1:200 in BB 1x). After the last wash with the TBS-T buffer, $80 \mu \mathrm{l}$ of TMB One solution was used as developer and the reaction was stopped by adding $80 \mu \mathrm{L}$ of $\mathrm{HCl} 1 \mathrm{M}$. Absorbance was measured at $450 \mathrm{~nm}$. BDNF levels are reported as $\mathrm{pg} / \mathrm{mL}$ normalized per total amount of protein.

\section{Data analysis}

Values are presented as mean \pm standard error of the mean (SEM) of $n$ experiments. Either a Student's $t$ test for independent means or a one-way analysis of variance (ANOVA) followed by a Newman-Keuls post hoc test, was used to define statistical differences between absolute values, which were considered significant at $P<0.05$ unless otherwise specified. Note that although the impact of several drugs and modulators are presented as percentage values for the sake of clarity, the statistical comparisons were always carried out using the absolute values.

\section{Results}

LPS induces time-dependent changes in BDNF cellular levels, an effect dependent upon adenosine $A_{2 A}$ receptor tonic activation

To explore the ability of $\mathrm{A}_{2 \mathrm{~A}} \mathrm{R}$ to modulate BDNF levels in microglial cells in response to an inflammatory stimulus, we used a microglial cell line (N9), which has been successfully used previously to dissect classical microglial responses (secretion of inflammatory mediators, microglial proliferation and phagocytosis) in inflammatory-like conditions [30,31]. N9 cells were activated with LPS, a component of the Gram-negative bacteria cell membrane, which is a well-characterized inflammatory stimulus able to induce microglial activation and the subsequent secretion of trophic factors, including BDNF (for example $[9,12])$.

We began testing the time course (3 up to 12 hours) of the impact of LPS $(100 \mathrm{ng} / \mathrm{mL})$ on the intracellular levels of BDNF. BDNF is synthesized as a precursor protein (pro-BDNF), which is subsequently cleaved intra- and/or extracellularly (by peptidases and convertases) to form the mature protein (mBDNF) $[19,32,33]$, which can be detected by Western blot analysis $(37.5$ and $13 \mathrm{kDa}$, respectively). In the present experimental conditions, LPS $(100 \mathrm{ng} / \mathrm{mL})$ did not affect the cellular levels of pro-BDNF at any given time point (Figure 1A,B, $P>0.05$ compared with non-treated cells). However, 6 hours of exposure to LPS induced a decrease of the cellular levels of the mature protein $(74.9 \pm 4.3 \%, n=7, P<0.001$ compared with nontreated cells), which returned to values similar to those observed in non-treated cells 6 hours later, that is, at 12 hours of exposure to LPS (Figure 1A,B).

We have previously reported that LPS is able to induce microgliosis and the production of pro-inflammatory mediators under $\mathrm{A}_{2 \mathrm{~A}} \mathrm{R}$ control [9]. In parallel, it is known that $\mathrm{A}_{2 \mathrm{~A}} \mathrm{R}$ modulates $\mathrm{BDNF}$ levels both in neurons [34] and in native tissue [35]. Since this effect has not yet been reported in microglia, we tested the ability of a supramaximal and selective concentration $(50 \mathrm{nM})$ of an $\mathrm{A}_{2 \mathrm{~A}} \mathrm{R}$ antagonist, SCH58261 [24], to control BDNF levels in the absence and in the presence of LPS. As shown in Figure 2, the $\mathrm{A}_{2 \mathrm{~A}} \mathrm{R}$ antagonist prevented the LPS-induced decrease of mBDNF at 6 hours $(129.5 \pm 23.04 \%, n=5, P<0.01$ compared with LPS-treated cells, Figures $2 \mathrm{~B}, \mathrm{D})$, whereas SCH58261 was devoid of effects on BDNF levels either when LPS has no effects (that is, at 3 or 12 hours; Figure 2A,C) or in the absence of LPS $(P>0.05$ compared with non-treated cells or LPS-treated cells for 3 and 12 hours). 


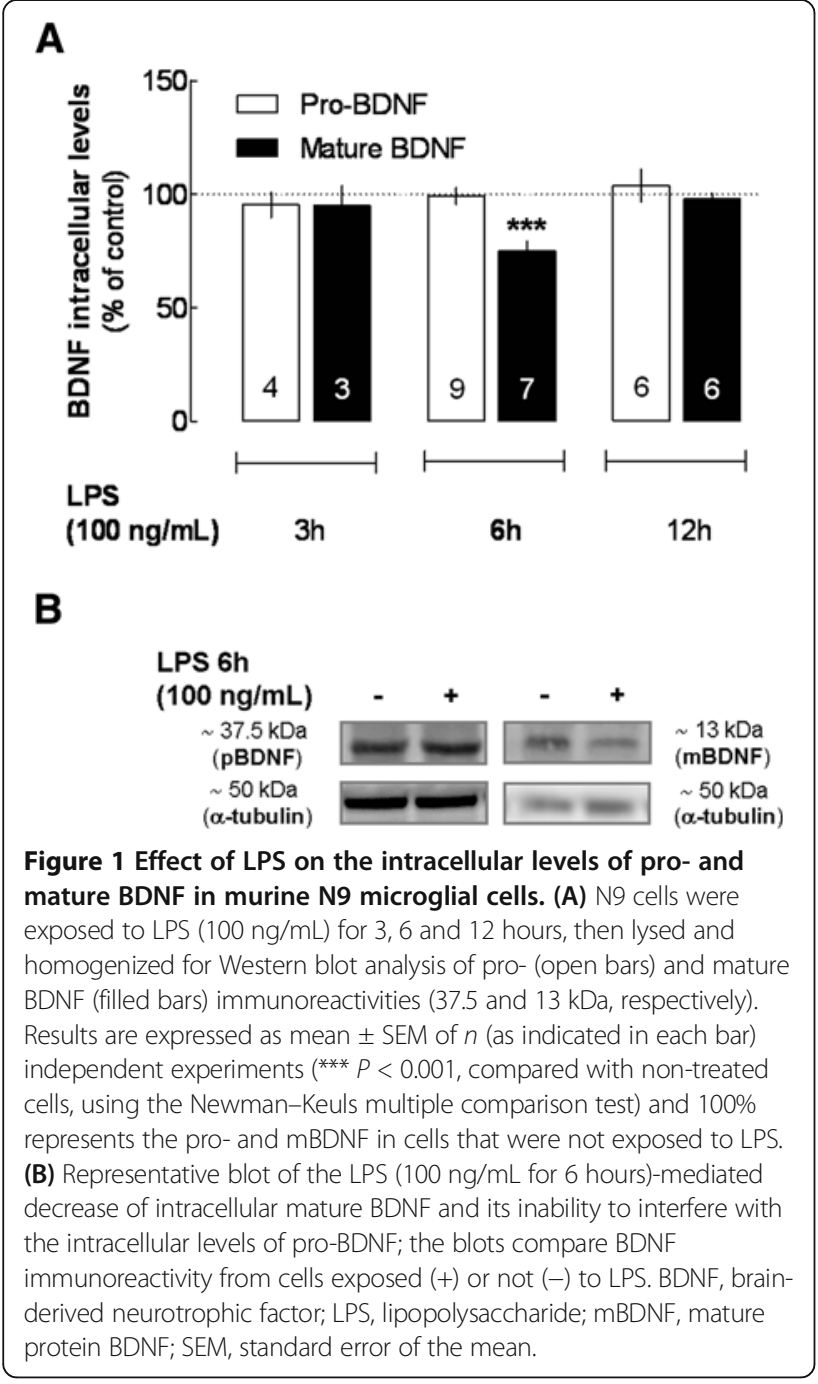

LPS-induced decrease of BDNF cellular levels is related to an increase of BDNF secretion, an effect dependent upon a tonic activation of $A_{2 A} R$

The LPS-induced decrease of mBDNF at 6 hours of exposure may be explained by changes in BDNF expression and/or secretion. The fact that LPS did not influence the levels of pro-BDNF (see Figures 1 and 2) suggests that changes in secretion are more likely to be involved. Thus, we tested the influence of LPS upon BDNF secretion by measuring free mature BDNF levels in the culture medium, as assessed by ELISA. Endogenous levels of BDNF in non-treated cells $(196.2 \pm 37.6 \mathrm{pg} / \mathrm{mL}, n=9$, Figure 3A) were increased by $147.3 \pm 12 \%(n=9, P<0.01)$ in the presence of LPS (100 ng/mL for 6 hours), reaching extracellular values of $272.1 \pm 51.3 \mathrm{pg} / \mathrm{mL}$ (Figure 3A,B). The $\mathrm{A}_{2 \mathrm{~A}} \mathrm{R}$ antagonist, SCH58261 (50 nM), notably prevented this LPS-induced BDNF secretion (93.6 $\pm 8.7 \%$, $n=9, P<0.01$ compared with LPS-treated cells, Figure $3 \mathrm{~B}$ ). These results indicate that $\mathrm{A}_{2 \mathrm{~A}} \mathrm{R}$ activation by endogenous adenosine is required to allow the LPSinduced secretion of BDNF. Accordingly, the presence of ADA (1 U/mL), which removes endogenous adenosine thus impairing $\mathrm{A}_{2 \mathrm{~A}} \mathrm{R}$ activation, also prevented the effect of LPS upon BDNF release (104.7 $\pm 4.2 \%, n=5, P<0.01$ compared with LPS-treated cells, Figure 3B).

\section{$A_{2 A} R$ control the LPS-induced secretion of BDNF through the CAMP-PKA pathway}

The key role of $A_{2 A} R$ in mediating the LPS-induced secretion of BDNF suggests that the direct activation of $A_{2 A} R$ should be able to trigger the release of BDNF from microglial N9 cells. Indeed, the selective $\mathrm{A}_{2 \mathrm{~A}} \mathrm{R}$ agonist, CGS21680 (30 nM), enhanced per se (that is, in the absence of LPS) the secretion of BDNF (146.2 $\pm 14.3 \%, n=4$, $P<0.05$ compared with non-treated cells) to an extent similar to the effect of LPS $(P>0.05$ compared with LPStreated cells), an effect prevented by the $\mathrm{A}_{2 \mathrm{~A}} \mathrm{R}$ antagonist SCH58261 (50 nM) $(96.3 \pm 10 \%, n=4, P<0.01$ compared with CGS21680-treated cells) (Figure 4A).

$\mathrm{A}_{2 \mathrm{~A}} \mathrm{R}$ are $\mathrm{G}$ protein-coupled receptors and most of their effects involve $\mathrm{AC}$ activation and the subsequent raise in cAMP levels, which activate PKA (for a review, see, for example, [36]). Accordingly, adenosine modulates peripheral immune responses through the activation of $\mathrm{A}_{2 \mathrm{~A}} \mathrm{R}$ and the recruitment of the cAMP-PKA pathway [6]. It has previously been reported that PKA notably plays a crucial role in the control of the depolarization-evoked release of BDNF from neurons [20]. Thus, we tested to see if the AC-cAMP-PKA pathway would control BDNF secretion from microglial cells. As shown in Figure 4B, the activation of $\mathrm{AC}$ with forskolin $(1 \mu \mathrm{M})$ or the cAMP analog 8-bromo-cAMP $(5 \mu \mathrm{M})$, mimicked the effect of LPS, triggering BDNF secretion (147.4 $\pm 9.1 \%, n=5, P<0.001$ compared with non-treated cells and $120.9 \pm 3.4 \%, n=5$, $P<0.01$ compared with non-treated cells) to an extent similar to that caused by LPS (both have $P>0.05$ compared with LPS-treated cells). Compatible with this scenario, we report that the PKA inhibitor H89 (1 $\mu \mathrm{M})$ prevented the effect of LPS upon BDNF secretion (95.8 \pm $7.7 \%, n=6, P<0.01$ compared with LPS-treated cells, Figure $4 C$ ), further suggesting that the tonic activation by endogenous adenosine of $\mathrm{A}_{2 \mathrm{~A}} \mathrm{R}$ operating through the cAMP-PKA pathway underlies the ability of LPS to trigger BDNF secretion.

Notably, we observed that H89 failed to modify the basal outflow of BDNF from microglial N9 cells (Figure 4C), indicating that the AC-cAMP-PKA pathway can be recruited by $\mathrm{A}_{2 \mathrm{~A}} \mathrm{R}$ to bolster the release of BDNF upon LPS-induced microgliosis, but does not mediate the constitutive release of BDNF. In contrast, the PKC inhibitor, chelerythrine (6 $\mu \mathrm{M})$, enhanced the constitutive outflow of BDNF (160.3 $\pm 12.3 \%, n=4, P<0.05$ compared with non-treated cells; Figure $4 C$ ), but failed to affect the LPS-induced secretion 

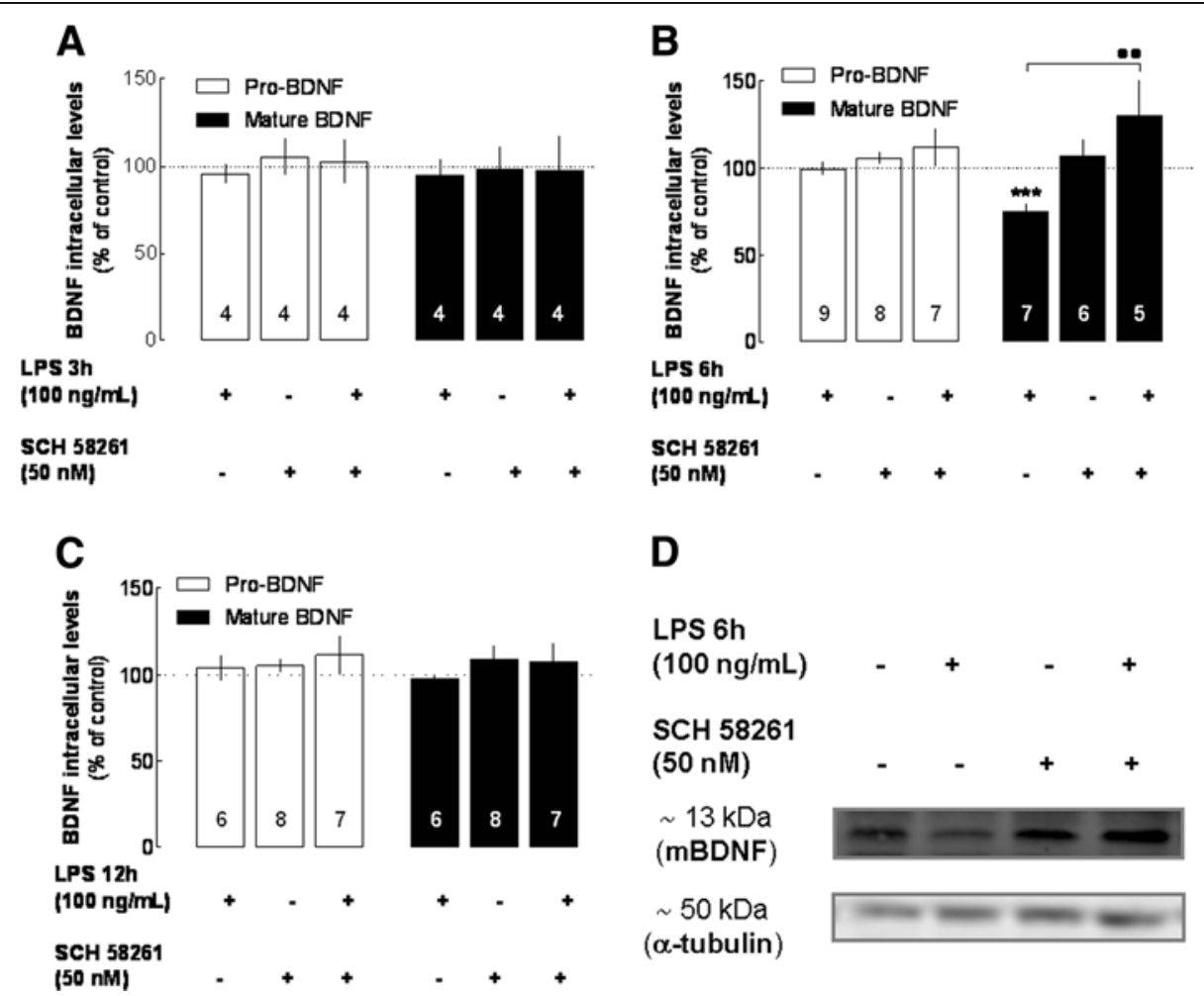

D

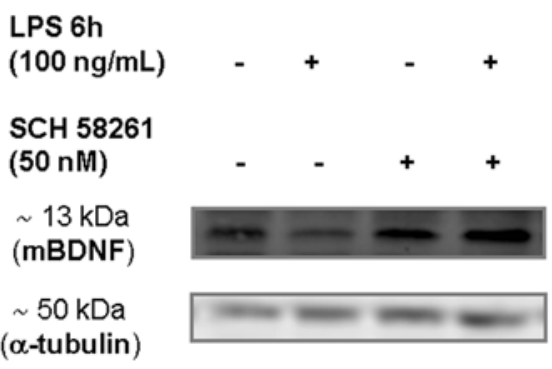

Figure 2 Effect of LPS on the intracellular levels of pro- and mature BDNF in the presence of a selective $A_{2 A} R$ antagonist in murine N9 microglial cells. The $A_{2 A} R$ antagonist SCH58261 (50 nM) prevented the LPS (100 ng/mL)-induced modification of mature BDNF levels selectively at 6 hours (B). In contrast, the $A_{2 A} R$ blockade failed to affect the levels of pro- and mature BDNF at 3 hours (A) or 12 hours (C) of LPS exposure. Note that $A_{2 A} R$ only affected BDNF levels when they were challenged with LPS. Results are expressed as mean \pm SEM of $n$ (as indicated in each bar) independent experiments (*** $P<0.001$, compared with non-treated cells; $. . P<0.01$, compared with LPS-treated cells, using the NewmanKeuls multiple comparison test) and 100\% represents the pro- and mBDNF in cells that were not exposed to LPS. (D) Representative blot of the modulation by SCH58261 of intracellular mature BDNF in cells challenged for 6 hours with LPS. We verified (not shown) that none of the vehicles of the tested drugs (water or dimethyl sulfoxide) modified BDNF levels. $A_{2 A} R, A_{2 A}$ receptor; BDNF, brain-derived neurotrophic factor; LPS, lipopolysaccharide; mBDNF, mature protein BDNF; SEM, standard error of the mean.

of BDNF $(146.4 \pm 15.0 \%, n=4, P>0.05$ compared with LPS-treated cells; Figure 4C). This indicates that the transducing pathways involved in the constitutive and LPS-induced release of BDNF are different and that the LPS-induced enhancement of BDNF secretion selectively recruits the $\mathrm{A}_{2 \mathrm{~A}} \mathrm{R}$ operating the cAMP-PKA pathway.

In accordance with our working hypothesis that the LPS-induced release of BDNF requires the recruitment of $\mathrm{A}_{2 \mathrm{~A}} \mathrm{R}$ and the activation of the AC-cAMP pathway, we expected to record an ability for CGS21680 (an activator of $\mathrm{A}_{2 \mathrm{~A}} \mathrm{R}$ ), forskolin (an activator of $\mathrm{AC}$ ) or 8-Br-cAMP to occlude the ability of LPS to enhance BDNF release. Surprisingly, we observed that the activation of the $\mathrm{A}_{2 \mathrm{~A}} \mathrm{R}-\mathrm{AC}$ cAMP system before the LPS challenge actually changed the set-up of the N9 cells to such an extent that the simultaneous presence of LPS and any of the activators of the $\mathrm{A}_{2 \mathrm{~A}} \mathrm{R}$-AC-cAMP axis (30 nM CGS21680, $1 \mu \mathrm{M}$ forskolin or $5 \mu \mathrm{M} 8$-Br-cAMP) now failed to modify $(P>0.05)$ the release of BDNF compared to the control (Figures $4 \mathrm{~A}, \mathrm{~B}$ ). This prompts the hypothesis that the LPS signaling pathway or the ability to release BDNF might be affected by this pre-exposure to these activators of the $\mathrm{A}_{2 \mathrm{~A}} \mathrm{R}-\mathrm{AC}$ cAMP axis, a question that warrants further detailed mechanistic investigation.

This different role for $\mathrm{A}_{2 \mathrm{~A}} \mathrm{R}$ in the control of LPS-induced enhancement of BDNF secretion (LPS requires the subsequent activation of $\mathrm{A}_{2 \mathrm{~A}} \mathrm{R}$, whereas the pre-activation of $\mathrm{A}_{2 \mathrm{~A}} \mathrm{R}$ inhibited the LPS-induced release of BDNF) led us to test the hypothesis that LPS might up-regulate $\mathrm{A}_{2 \mathrm{~A}} \mathrm{R}$ to bolster BDNF secretion from N9 microglial cells. As shown in Figure 5, both Western blot (Figure 5A,B) and immunocytochemical (Figure $5 \mathrm{C}$ ) analysis of N9 cells revealed an enhancement of $\mathrm{A}_{2 \mathrm{~A}} \mathrm{R}$ immunoreactivity at the same time point where LPS-induced enhancement of BDNF secretion was observed (that is, at 6 hours). The temporal correlation between the enhancement of $\mathrm{A}_{2 \mathrm{~A}} \mathrm{R}$ density and the PKAdependent increase of BDNF secretion suggests that LPSinduced PKC-PKA shifting in the regulation of BDNF secretion may be triggered by the increased $A_{2 A} R$ signaling subsequent to an increase in receptor density and activation. 
A

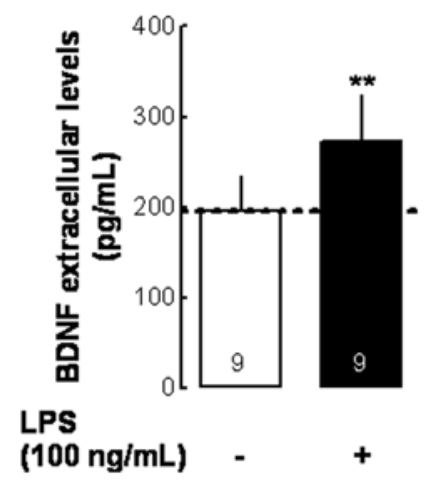

B

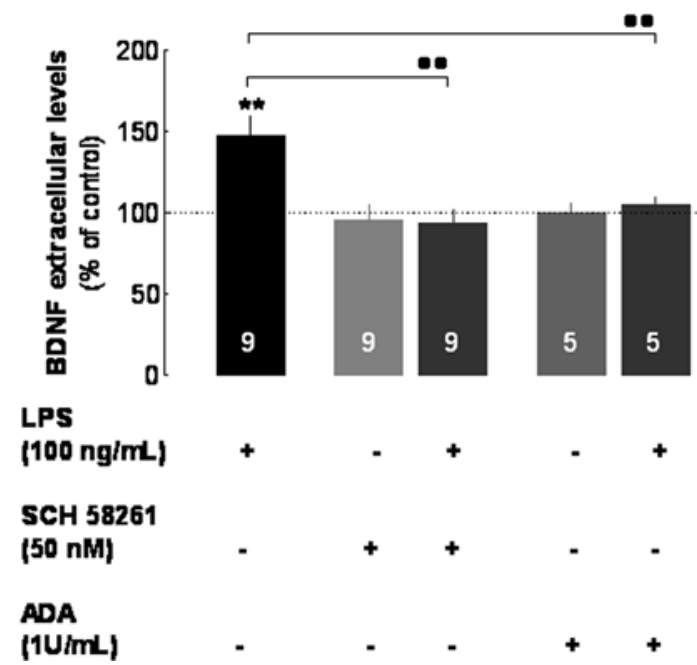

Figure 3 Endogenous extracellular adenosine, through activation of $A_{2 A} R$, mediates the LPS-induced enhancement of BDNF secretion from microglial $\mathbf{N 9}$ cells. Cells were incubated with LPS $\left(100 \mathrm{ng} / \mathrm{mL}\right.$ for 6 hours) in the absence or in the presence of the $A_{2 A} R$ antagonist, SCH58261 (50 nM) or in the absence or presence of adenosine deaminase (ADA, $1 \mathrm{U} / \mathrm{mL}$ ), which converts adenosine into its inactive metabolite, inosine. The incubation medium was collected to quantify the extracellular free mature BDNF by ELISA. (A) Comparison between absolute values of BDNF (pg/mL) in the absence and in the presence of LPS. (B) LPS increased the extracellular levels of BDNF, an effect prevented by $A_{2 A} R$ antagonism and by adenosine removal from the medium with ADA (percentage of effect; 100\% represents BDNF levels in cells that were not exposed to LPS). Results are expressed as mean \pm SEM of $n$ (as indicated in each bar) independent experiments $(* * P<0.01$, compared with nontreated cells; $\boldsymbol{~} P<0.01$, compared with LPS-treated cells, using the Newman-Keuls multiple comparison test). We verified (not shown) that none of the vehicles of the tested drugs (water or dimethyl sulfoxide) modified BDNF levels. $A_{2 A} R, A_{2 A}$ receptor; $A D A$, adenosine deaminase; BDNF, brain-derived neurotrophic factor; LPS, lipopolysaccharide; SEM, standard error of the mean.

A

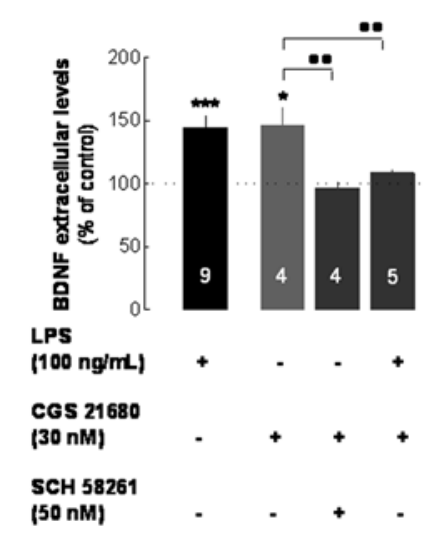

B

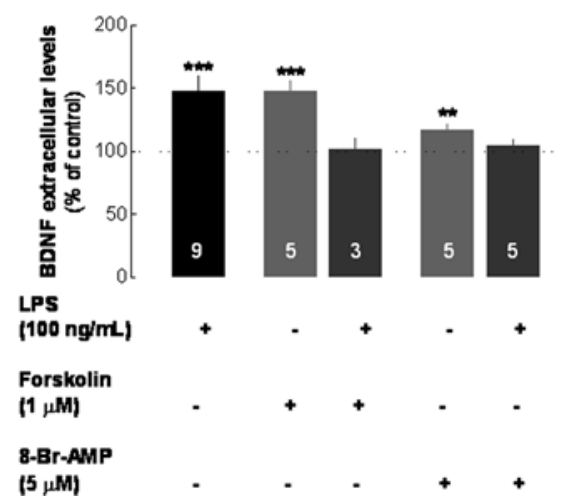

C

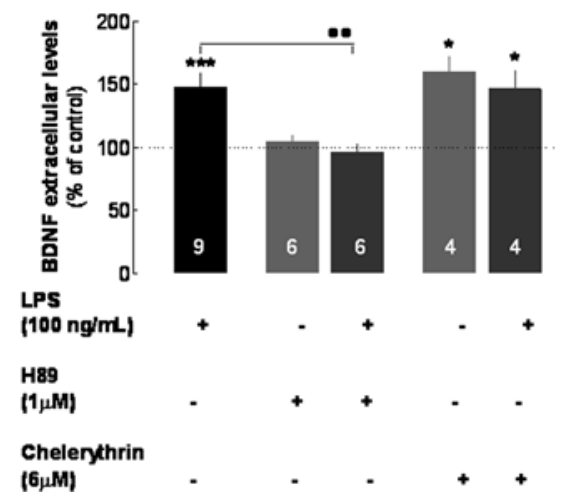

Figure 4 The LPS-induced enhancement of BDNF secretion mediated by $A_{2 A} R$ involves the recruitment of the AC-CAMP-PKA transducing pathway, whereas PKC controls the constitutive release of BDNF from N9 microglial cells. In all experiments, the medium was collected after 6 hours for quantitative analysis of extracellular BDNF (ELISA). (A) Cells were incubated with the $A_{2 A} R$ agonist CGS21680 (30 $\mathrm{nM})$ in the absence or in the presence of the $A_{2 A} R$ antagonist SCH58261 (50 nM) or LPS (100 ng/mL). (B) Cells were incubated with the adenylyl cyclase (AC) activator, forskolin (1 $\mu \mathrm{M})$ or with the CAMP analog, 8-Br-cAMP $(5 \mu \mathrm{M})$ in the absence and in the presence of LPS (100 ng/mL). (C) Cells were incubated with the PKA inhibitor, H89 $(1 \mu \mathrm{M})$ or with the PKC inhibitor, chelerythrine $(6 \mu \mathrm{M})$ in the absence and in the presence of LPS $(100 \mathrm{ng} / \mathrm{mL})$. Results are expressed as mean \pm SEM of $n$ (as indicated in each bar) independent experiments $\left(* * *<0.001,{ }^{* *} P<0.01,{ }^{*} P<0.05\right.$, compared with non-treated cells; $\cdot$ P $<0.01$, compared with LPS-treated cells, using the Newman-Keuls multiple comparison test) and $100 \%$ represents the pro- and mBDNF in cells that were not exposed to LPS. We verified (not shown) that none of the vehicles of the tested drugs (water or dimethyl sulfoxide) modified BDNF levels. $A_{2 A} R, A_{2 A}$ receptor; $A D A$, adenosine deaminase; BDNF, brain-derived neurotrophic factor; CAMP, cyclic AMP; LPS, lipopolysaccharide; PKA, protein kinase A; PKC, protein kinase C; SEM, standard error of the mean. 


\section{LPS promotes microglial proliferation, an effect} dependent upon BDNF and $A_{2 A} R$ tonic activation

Given that both $\mathrm{BDNF}$ and $\mathrm{A}_{2 \mathrm{~A}} \mathrm{R}$ activation promote neuroinflammation and $\mathrm{A}_{2 \mathrm{~A}} \mathrm{R}$ was previously proposed to be required for microglial proliferation [37], we next aimed to extend understanding of the tight interplay between $\mathrm{BDNF}$ and $\mathrm{A}_{2 \mathrm{~A}} \mathrm{R}$ in the context of the control of microglial proliferation, a key process for sustaining neuroinflammation. We posited that one of the functions of BDNF released under LPS stimulation of microglial cells might be to promote their proliferation in order to 'feed' microgliosis, an effect which might also be controlled by $\mathrm{A}_{2 \mathrm{~A}} \mathrm{R}$. To begin probing this hypothesis, we first tested the impact of an antibody that specifically recognizes and sequesters BDNF on the LPS-induced proliferation of N9 microglial cells. As anticipated, LPS (100 ng/mL for 6 hours) induced a clear proliferation of N9 microglial cells $(170.5 \pm 9.2 \%, n=6, P<0.01$ compared with non-treated cells). Notably, this effect was prevented when the cells were simultaneously incubated with the antibody anti-BDNF $(79.4 \pm 3.5 \%, n=3, P<0.001$ compared with LPS-treated cells; Figure 6A,B). Furthermore, in line with the ability of $\mathrm{A}_{2 \mathrm{~A}} \mathrm{R}$ to control LPS-induced BDNF secretion, we observed that the $A_{2 A} R$ antagonist, SCH58261 (50 nM), prevented the LPS-induced increase of N9 microglial cell proliferation $(90.4 \pm 8.1 \%, n=3$, $P<0.01$ compared with LPS-treated cells, Figure 6A,C).

In order to disentangle whether the $\mathrm{A}_{2 \mathrm{~A}} \mathrm{R}$ blockade was only preventing BDNF secretion or also the impact of BDNF on microglial proliferation, we then evaluated the

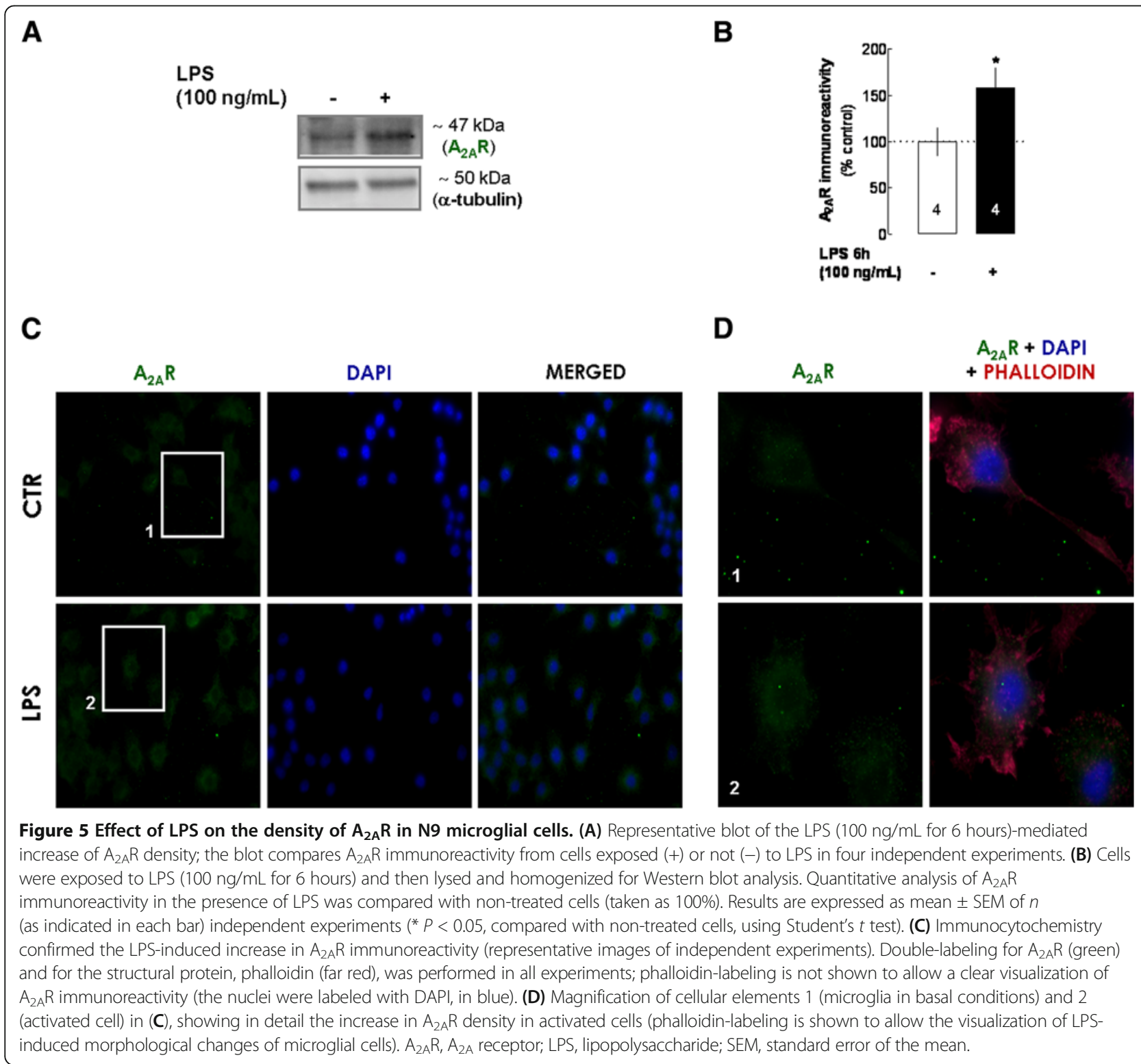


ability of exogenously added BDNF to directly trigger the proliferation of N9 microglial cells, as well as the ability of SCH58261 to modulate this eventual effect. BDNF $(20 \mathrm{ng} / \mathrm{mL})$ increased the proliferation of $\mathrm{N} 9$ microglial cells (242 $\pm 48 \%, n=3, P<0.01$ compared with non-treated cells), an effect prevented by the antibody anti-BDNF (104.3 $\pm 4.1 \%, n=3, P<0.05$ compared with BDNF-treated cells, data not shown) and by the $\mathrm{A}_{2 \mathrm{~A}} \mathrm{R}$ blockade (147.7 \pm $47 \%, n=3, P<0.05$ compared with BDNF-treated cells) or removal of endogenous adenosine with $1 \mathrm{U} / \mathrm{mL}$ of ADA (111.2 $\pm 29 \%, n=3, P<0.01$ compared with BDNF-treated cells, Figure 6D,E).

Finally, we attempted to extend the $\mathrm{A}_{2 \mathrm{~A}} \mathrm{R}$-mediated control of BDNF-induced proliferation from the context of N9 microglial cells to that of mouse microglia. These mouse primary cultures of microglia $(n=2$ in triplicate) were exposed to LPS $(100 \mathrm{ng} / \mathrm{mL})$ or to BDNF $(20 \mathrm{ng} / \mathrm{mL})$ for 6 hours: both LPS $(251.1 \pm 12.8 \%, P<0.01$ compared with non-treated cells, Figure 7A,B) and BDNF (201.1 \pm $2.6 \%, P<0.05$ compared with non-treated cells, Figure 7A, $B)$ increased primary microglial proliferation, an effect prevented by the $\mathrm{A}_{2 \mathrm{~A}} \mathrm{R}$ blockade with $\mathrm{SCH} 58261(50 \mathrm{nM})$.

\section{Discussion}

The present study suggest two major conclusions: 1) the activation of microglial cells with LPS triggers a release of BDNF, which plays a key autocrine or paracrine role by stimulating microglial proliferation; 2) both the LPSinduced release of BDNF as well as the resulting proliferation of microglia is prevented by the blockade of adenosine $\mathrm{A}_{2 \mathrm{~A}} \mathrm{R}$.

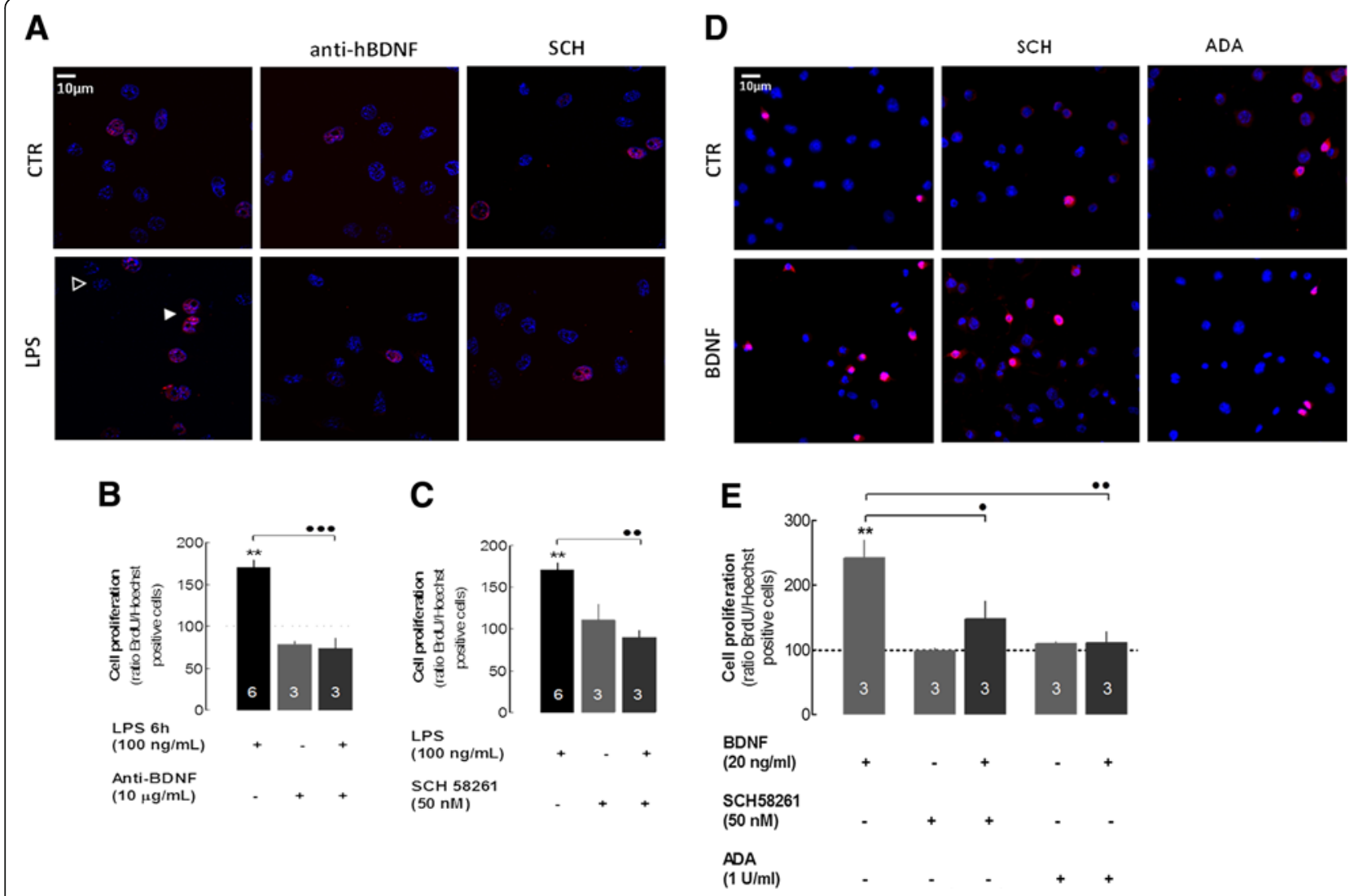

Figure 6 LPS triggers microglial N9 proliferation in a manner dependent on extracellular BDNF and $A_{2 A} R$ activation. Cells were exposed to LPS (100 ng/mL) for 6 hours in the presence of BrdU for the last 2 hours. Proliferation was quantified as the number of BrdU-labeled nuclei (red) and expressed as a percentage of the total number of DAPI-labeled nuclei (blue). (A) Representative images illustrating the ability of LPS to enhance N9 microglial cell proliferation, an effect prevented both by an anti-BDNF antibody (10 $\mu \mathrm{g} / \mathrm{mL})$ and by the selective $\mathrm{A}_{2 \mathrm{~A}} \mathrm{R}$ antagonist, SCH58261 (50 nM). Average quantitative analysis shows that anti-BDNF antibody (B) or SCH58261 (C) prevents LPS-induced proliferation. (D) Representative images illustrating the ability of added BDNF $(20 \mathrm{ng} / \mathrm{mL})$ to enhance $N 9$ microglial cells proliferation, an effect prevented both by the selective $A_{2 A} R$ antagonist, SCH58261 (50 nM) and by adenosine deaminase (ADA, $1 \mathrm{U} / \mathrm{mL}$ ). Average quantitative analysis shows the ability of SCH58261 (50 nM) and ADA (1 U/mL) to prevent BDNF effects $(\mathbf{E})$. Results are expressed as mean \pm SEM of $n$ (as indicated in each bar) independent experiments $(* * P<0.01$, compared with non-treated cells; $\ldots P<0.001, . . P<0.01$, compared with LPS-treated cells; $\boldsymbol{*} P<0.01, \cdot P<0.05$ compared with BDNF-treated cells using the Newman-Keuls multiple comparison test) and $100 \%$ represents proliferation of cells that were not exposed to LPS. $A_{2 A} R, A_{2 A}$ receptor; $A D A$, adenosine deaminase; BDNF, brain-derived neurotrophic factor; LPS, lipopolysaccharide; SEM, standard error of the mean. 
In response to noxious stimuli, microglia become activated by changing their morphology, proliferating and releasing molecules, some considered to be neurotoxic and others neuroprotective [1]. Irrespective of the nature of the released substances, microglial responses in the central nervous system must be tightly regulated since the sustained activation of microglia results in a chronic neuroinflammatory process, which is involved in neurodegeneration. Neurotrophic factors, namely BDNF, which are produced and secreted by microglial cells [21,38,39], have the ability to protect neurons and to promote neuronal repair in pathologic-like conditions [11-13]. Although the physiological role of BDNF in neuronal survival/repair has been extensively investigated, the autocrine/paracrine function of BDNF secreted by microglial cells has not been addressed and may actually play a deleterious role. Thus, BDNF can actually behave as a switch by promoting an autocrine action in microglial cells, which may lead to their sustained activation, as occurs in spinal cord cells during neuropathic pain [17]: in this disease, BDNF exacerbates pain hypersensitivity, and strategies to prevent BDNF-mediated microgliosis are considered to have therapeutic potential $[18,40]$. The present study with cultured N9 microglial cells provides the first direct demonstration for a key autocrine/paracrine role of BDNF in the LPSinduced proliferation of microglial cells: thus, LPS triggers the secretion of BDNF, which we showed to be directly responsible for the proliferation of microglial cells.

The second major novel conclusion of this study was the ability of the $\mathrm{A}_{2 \mathrm{~A}} \mathrm{R}$ blockade to prevent LPS-induced microglial proliferation, as a result of the dual ability of $\mathrm{A}_{2 \mathrm{~A}} \mathrm{R}$ to control the LPS-induced secretion of BDNF and the ability of this BDNF to trigger microglial proliferation. These observations are in agreement with the ability of the $\mathrm{A}_{2 \mathrm{~A}} \mathrm{R}$ blockade to control in vitro microglial proliferation [37]; they are also heralded by the numerous reports showing that $\mathrm{A}_{2 \mathrm{~A}} \mathrm{R}$ controls microglial activation, namely responses triggered by LPS $[8,41]$, as well as microgliosis in animal models of inflammatory disease [9,42-44]. In particular, the present results that both the induced secretion of BDNF as well as its impact on microglial cells are dependent on $\mathrm{A}_{2 \mathrm{~A}} \mathrm{R}$ activation, provide the first direct demonstration for a tight interplay between $\mathrm{A}_{2 \mathrm{~A}} \mathrm{R}$ and BDNF signaling in glial cells, extending the previously reported tight interaction between $\mathrm{A}_{2 \mathrm{~A}} \mathrm{R}$ and different neurotrophic factors in the control of neuronal responses [45-47]. In contrast to neuronal interactions between BNDF and $\mathrm{A}_{2 \mathrm{~A}} \mathrm{R}$, which were revealed in physiological-like processes, the interaction between $A_{2 A} R$ and BDNF in microglial cells seems to occur selectively under pathologic-like conditions typified by microglial activation. Thus, the effect of $A_{2 \mathrm{~A}} \mathrm{R}$ is not observed in the absence of LPS and the LPS-induced

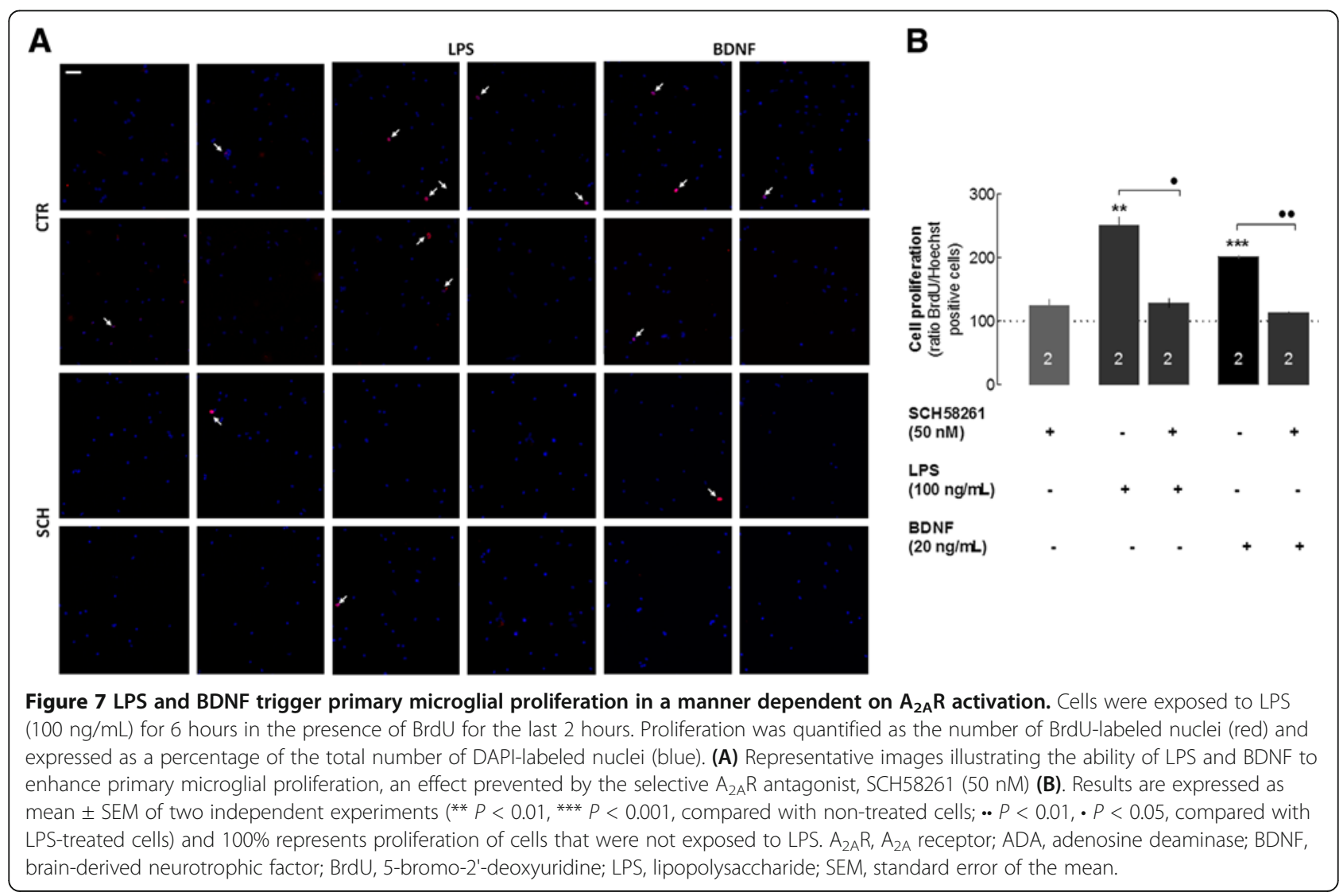




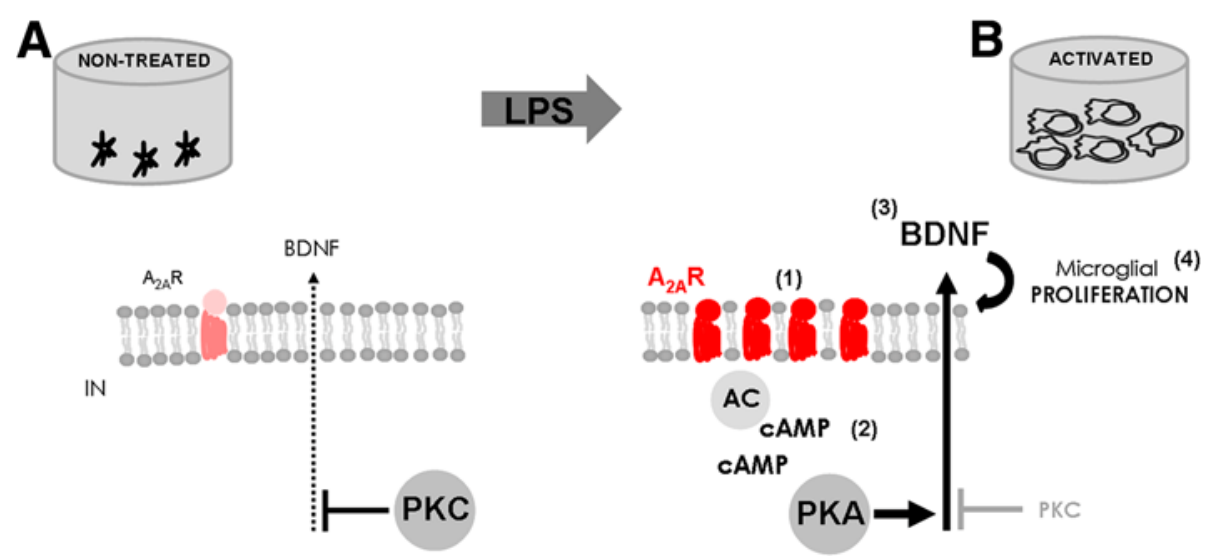

Figure 8 Schematic representation of the role of $A_{2 A} R$ in the control of BDNF release and microglial proliferation selectively in activated microglia. (A) Constitutive release of BDNF is under the control of PKC (non-treated cells). (B) In the presence of an inflammatory trigger, LPS, the increase in $A_{2 A} R$ density (1) and the subsequent downstream activation of AC-CAMP-PKA (2) prevails over PKC actions, inducing an increase in BDNF release (3), which increases microglial proliferation (4). AC, adenylyl cyclase; CAMP, cyclic AMP; IN, intracellular compartment; PKA, protein kinase A; PKC, protein kinase C.

release of $\mathrm{BDNF}$ is notably time-dependent and timecoincident with the increase in $\mathrm{A}_{2 \mathrm{~A}} \mathrm{R}$ density, strongly suggesting a role for the up-regulation of $\mathrm{A}_{2 \mathrm{~A}} \mathrm{R}$ in activated microglia as a trigger for this interaction, in agreement with the previously reported selective role of $\mathrm{A}_{2 \mathrm{~A}} \mathrm{R}$ in the pathophysiology of neuroinflammation $[9,44,48-50]$. It is important to recognize that the present results are in general agreement with the observation that it is the blockade of $\mathrm{A}_{2 \mathrm{~A}} \mathrm{R}$ that prevents neuroinflammation, which is in clear contrast with the anti-inflammatory effect resulting from $\mathrm{A}_{2 \mathrm{~A}} \mathrm{R}$ activation in the control of peripheral inflammation [6] or central pathological conditions, in particular when peripheral cells invade the central nervous system, as occurs through disruption of the blood-brain barrier, where immunosuppressive actions may be mediated by $\mathrm{A}_{2 \mathrm{~A}} \mathrm{R}$ activation rather than blockade $[51,52]$. The mechanism underlying this contradiction remains to be elucidated. The impact of $\mathrm{A}_{2 \mathrm{~A}} \mathrm{R}$ in controlling inflammation may depend on the type of immune cell involved, as well as the particular conditions found in the brain parenchyma [8], as previously discussed [53]. Considering that the $\mathrm{A}_{2 \mathrm{~A}} \mathrm{R}$ gene has independent promoters [54], region-specific transcriptional control of $\mathrm{A}_{2 \mathrm{~A}} \mathrm{R}$ may explain differences between central and peripheral immune responses.

The final interesting conclusion from this study is the observation that LPS redirects the intracellular pathway involved in the regulation of BDNF secretion from PKC to PKA. Considering the parallel increase in $A_{2 A} R$ density, this shift is likely due to an increase in $A_{2 A} R$ signaling. Indeed, the basal outflow of BDNF seems to be affected by a blockade of PKC but not of PKA; in contrast, the LPSinduced outflow of BDNF, shown to be mediated by the endogenous activation of the up-regulated $A_{2 A} R$, was prevented by PKA rather than PKC inhibition, suggesting a reorganization of the control of BDNF outflow upon microglial activation by LPS (Figure 8 ).

\section{Conclusion}

In inflammatory conditions microglial cells are activated and proliferate, which is a beneficial response if selflimited, but can become detrimental if sustained. The present study shows that BDNF secretion upon microglial activation plays an autocrine/paracrine role bolstering microglial proliferation, which may drive sustained microgliosis. Furthermore, we provide the first demonstration that adenosine $\mathrm{A}_{2 \mathrm{~A}} \mathrm{R}$ play a key dual role in the control of BDNF secretion upon microglial activation, as well as on BDNF-induced proliferation of microglial cells. This provides the first direct demonstration for the interplay between $A_{2 A} R$ and BDNF in glial cells and provides a novel mechanistic insight into the therapeutic potential of $A_{2 A} R$ antagonists to control neurodegenerative conditions where chronic neuroinflammation is present.

\section{Abbreviations}

$A_{2 A} R: A_{2 A}$ receptor; $A C$ : adenylyl cyclase; $A D A$ : adenosine deaminase; ANOVA: analysis of variance; BCA: bicinchoninic acid; BDNF: brain-derived neurotrophic factor; BrdU: 5-bromo-2'-deoxyuridine; BSA: bovine serum albumin; CAMP: cyclic AMP; ECF: enhanced chemofluorescence reagent; EDTA: ethylenediamine tetraacetic acid; ELISA: enzyme-linked immunosorbent assay; LPS: lipopolysaccharide; mBDNF: mature protein BDNF; PBS: phosphate-buffered saline; PKA: protein kinase A; PKC: protein kinase C; PMSF: phenylmethylsulfonyl fluoride; pro-BDNF: precursor protein BDNF; PVDF: polyvinylidene difluoride; RT: room temperature; SDS: sodium dodecyl sulfate; SEM: standard error of the mean; TBS: Tris-buffered saline.

\section{Competing interests}

The authors declare that they have no competing interests.

\section{Authors' contribution}

CG was responsible for the quantification of extracellular BDNF (ELISA), intracellular BDNF (Western bloting, with the help of RS), primary cultures of 
microglia (with the help of JG) and for the experimental design, for coordinating the project and organizing the manuscript with the help and under the supervision of RAC. RF was in charge with proliferation assays and image selection and organization, as well as scientific advice. JG performed Western blot analysis of p38 and IL-1beta detection (ELISA). DR performed Western blot analysis and immunocytochemistry for A2AR. NG performed A2AR signaling experiments. All authors read and approved the final manuscript.

\section{Acknowledgments}

The authors wish to thank Professor Claudia Verderio from the Nationa Research Council, Institute of Neuroscience and Department of Medical Pharmacology, Milan, Italy, for her generous gift of the murine N9 microglial cell line and Elisabete Augusto for her constructive remarks. The anti-BDNF antibody was kindly provided by Professor Carlos Duarte from the Center for Neuroscience and Cell Biology, Portugal. This work was supported by FCT, Portugal. The cell line was maintained in the facilities of the Microbiology Department of the Faculty of Medicine, University of Coimbra, Portugal; the authors wish to thank Professor Teresa Gonçalves for her generous help.

\section{Author details}

${ }^{1}$ Center for Neuroscience and Cell Biology, University of Coimbra, Largo Marquês de Pombal, Coimbra 3004-517, Portugal. ${ }^{2}$ FMUC - Faculty of Medicine, University of Coimbra, Coimbra 3004-504, Portugal. ${ }^{3}$ Faculty of Pharmacy, University of Coimbra, Coimbra 3000-548, Portugal.

Received: 7 March 2012 Accepted: 18 January 2013

Published: 30 January 2013

\section{References}

1. Sastre M, Richardson JC, Gentleman SM, Brooks DJ: Inflammatory risk factors and pathologies associated with Alzheimer's disease. Curr Alzheimer Res 2011, 8(2):132.

2. Tansey MG, Goldberg MS: Neuroinflammation in Parkinson's disease: its role in neuronal death and implications for therapeutic intervention. Neurobiol Dis 2010, 37(3):510.

3. Reitz C, Brayne C, Mayeux R: Epidemiology of Alzheimer disease. Nat Rev Neurol 2011, 7(3):137

4. Kettenmann H, Hanisch UK, Noda M, Verkhratsky A: Physiology of microglia. Physiol Rev 2011, 91(2):461.

5. Di Virgilio F, Ceruti S, Bramanti P, Abbracchio MP: Purinergic signalling in inflammation of the central nervous system. Trends Neurosci 2009, 32(2):79.

6. Ohta A, Sitkovsky M: Role of G-protein-coupled adenosine receptors in downregulation of inflammation and protection from tissue damage. Nature 2001, 414(6866):916

7. Orr AG, Orr AL, Li XJ, Gross RE, Traynelis SF: Adenosine $A_{(2 A)}$ receptor mediates microglial process retraction. Nat Neurosci 2009, 12(7):872.

8. Dai SS, Zhou YG, Li W, An JH, Li P, Yang N, Chen XY, Xiong RP, Liu P, Zhao $Y$, Shen $H Y$, Zhu PF, Chen JF: Local glutamate level dictates adenosine $A_{2 A}$ receptor regulation of neuroinflammation and traumatic brain injury. J Neurosci 2010, 30(16):5802.

9. Rebola N, Simões AP, Canas PM, Tomé AR, Andrade GM, Barry CE, Agostinho PM, Lynch MA, Cunha RA: Adenosine $A_{2 A}$ receptors control neuroinflammation and consequent hippocampal neuronal dysfunction. J Neurochem 2011, 117(1):100.

10. Sebastião $A M$, Ribeiro JA: Triggering neurotrophic factor actions through adenosine $A_{2 A}$ receptor activation: implications for neuroprotection. $\mathrm{Br} J$ Pharmacol 2009, 158(1):15.

11. Batchelor PE, Liberatore GT, Porritt MJ, Donnan GA, Howells DW: Inhibition of brain-derived neurotrophic factor and glial cell line-derived neurotrophic factor expression reduces dopaminergic sprouting in the injured striatum. Eur J Neurosci 2000, 12(10):3462.

12. Espinosa-Oliva AM, de Pablos RM, Villarán RF, Argüelles S, Venero JL, Machado A, Cano J: Stress is critical for LPS-induced activation of microglia and damage in the rat hippocampus. Neurobiol Aging 2011, 32(1):85

13. Madinier A, Bertrand N, Mossiat C, Prigent-Tessier A, Beley A, Marie C, Garnier P: Microglial involvement in neuroplastic changes following focal brain ischemia in rats. PLoS One 2010, 4(12):e8101.

14. Chen JF, Sonsalla PK, Pedata F, Melani A, Domenici MR, Popoli P, Geiger J, Lopes LV, de Mendonça A: Adenosine $A_{2 A}$ receptors and brain injury: broad spectrum of neuroprotection, multifaceted actions and 'fine tuning' modulation. Prog Neurobio/ 2007, 83(5):310.

15. Gomes CV, Kaster MP, Tomé AR, Agostinho PM, Cunha RA: Adenosine receptors and brain diseases: neuroprotection and neurodegeneration. Biochim Biophys Acta 2011, 1808(5):1380

16. Jiang Y, Wei N, Lu T, Zhu J, Xu G, Liu X: Intranasal brain-derived neurotrophic factor protects brain from ischemic insult via modulating local inflammation in rats. Neuroscience 2011, 172:398.

17. Ulmann L, Hatcher JP, Hughes JP, Chaumont S, Green PJ, Conquet F, Buell $G N$, Reeve AJ, Chessell IP, Rassendren F: Up-regulation of $P_{2 x_{4}}$ receptors in spinal microglia after peripheral nerve injury mediates BDNF release and neuropathic pain. J Neurosci 2008, 28(44):11263.

18. Zhou LJ, Yang T, Wei X, Liu Y, Xin WJ, Chen Y, Pang RP, Zang Y, Li YY, Liu $X G$ : Brain-derived neurotrophic factor contributes to spinal long-term potentiation and mechanical hypersensitivity by activation of spinal microglia in rat. Brain Behav Immun 2011, 25(2):322.

19. Lessmann $V$, Brigadski T: Mechanisms, locations, and kinetics of synaptic BDNF secretion: an update. Neurosci Res 2009, 65:11

20. Kuczewski N, Porcher C, Ferrand N, Fiorentino H, Pellegrino C, Kolarow R, Lessmann V, Medina I, Gaiarsa JL: Backpropagating action potentials trigger dendritic release of BDNF during spontaneous network activity. J Neurosci 2008, 28:7013.

21. Trang $T$, Beggs $S$, Wan $X$, Salter MW: $P_{2 \times 4}$-receptor-mediated synthesis and release of brain-derived neurotrophic factor in microglia is dependent on calcium and p38-mitogen-activated protein kinase activation. J Neurosci 2009, 29(11):3518.

22. Carreira BP, Morte Ml, Carvalho CM, Araújo IM: Assessing the influence of neuroinflammation on neurogenesis: in vitro models using neural stem cells and microglia as valuable research tools. In Neural Stem Cells and Therapy. Edited by Tao S.: InTech; 2012. doi:10.5772/30723.

23. Canas P, Rebola N, Rodrigues RJ, Oliveira CR, Cunha RA: Increased adenosine $A_{2 A}$ immunoreactivity in activated rat microglia in culture. FENS Abstract 2004, 2:A223.9.

24. Lopes LV, Halldner L, Rebola N, Johansson B, Ledent C, Chen JF, Fredholm $B B$, Cunha RA: Binding of the prototypical adenosine $A_{(2 A)}$ receptor agonist CGS 21680 to the cerebral cortex of adenosine $A_{(1)}$ and $A_{(2 A)}$ receptor knockout mice. Br J Pharmacol 2004, 141(6):1006.

25. Cunha RA, Ribeiro JA: Purinergic modulation of $\left[{ }^{3} \mathrm{H}\right] \mathrm{GABA}$ release from rat hippocampal nerve terminals. Neuropharmacology 2000, 39:1156.

26. Rebola N, Sebastião AM, de Mendonça A, Oliveira CR, Ribeiro JA, Cunha RA: Enhanced adenosine $A_{2 A}$ receptor facilitation of synaptic transmission in the hippocampus of aged rats. J Neurophysiol 2003, 90:1295.

27. Inagaki T, Begum T, Reza F, Horibe S, Inaba M, Yoshimura Y, Komatsu Y: Brain-derived neurotrophic factor-mediated retrograde signaling required for the induction of long-term potentiation at inhibitory synapses of visual cortical pyramidal neurons. Neurosci Res 2008, 61:192.

28. Fontinha BM, Diógenes MJ, Ribeiro JA, Sebastião AM: Enhancement of long-term potentiation by brain-derived neurotrophic factor requires adenosine $A_{2 A}$ receptor activation by endogenous adenosine. Neuropharmacology 2008, 54(6):924.

29. Horner PJ, Power AE, Kempermann G, Kuhn HG, Palmer TD, Winkler J, Thal $\sqcup$, Gage FH: Proliferation and differentiation of progenitor cells throughout the intact adult rat spinal cord). J Neurosci 2000, 20(5):2218.

30. Ferreira R, Santos T, Cortes L, Cochaud S, Agasse F, Silva AP, Xapelli S, Malva JO: Neuropeptide $Y$ inhibits interleukin-1 beta-induced microglia motility. J Neurochem 2012, 120(1):93.

31. Ferreira R, Santos T, Viegas M, Cortes L, Bernardino L, Vieira OV, Malva JO: Neuropeptide $Y$ inhibits interleukin- $1 \beta$-induced phagocytosis by microglial cells. J Neuroinflammation 2011, 8:169.

32. Lee R, Kermani P, Teng KK, Hempstead BL: Regulation of cell survival by secreted proneurotrophins. Science 2001, 294(5548):1945

33. Mowla SJ, Farhadi HF, Pareek S, Atwal JK, Morris SJ, Seidah NG, Murphy RA: Biosynthesis and post-translational processing of the precursor to brainderived neurotrophic factor. J Biol Chem 2001, 276(16):12660.

34. Jeon SJ, Rhee SY, Ryu JH, Cheong JH, Kwon K, Yang SI, Park SH, Lee J, Kim $\mathrm{HY}$, Han $\mathrm{SH}$, Ko KH, Shin $\mathrm{CY}$ : Activation of adenosine $\mathrm{A}_{2 \mathrm{~A}}$ receptor up-regulates BDNF expression in rat primary cortical neurons. Neurochem Res 2011, 36(12):2259.

35. Tebano MT, Martire A, Potenza RL, Grò C, Pepponi R, Armida M, Domenici $M R$, Schwarzschild MA, Chen JF, Popoli P: Adenosine $A_{(2 A)}$ receptors are required for normal BDNF levels and BDNF-induced potentiation of 
synaptic transmission in the mouse hippocampus. J Neurochem 2008, 104(1):279.

36. Fredholm BB, Chen JF, Cunha RA, Svenningsson P, Vaugeois JM: Adenosine and brain function. Int Rev Neurobiol 2005, 63:191.

37. Gebicke-Haerter PJ, Christoffel F, Timmer J, Northoff H, Berger M, Van Calker $D$ : Both adenosine $A_{1}$ - and $A_{2}$-receptors are required to stimulate microglial proliferation. Neurochem Int 1996, 29(1):37.

38. Fujita R, Ma Y, Ueda H: Lysophosphatidic acid-induced membrane ruffling and brain-derived neurotrophic factor gene expression are mediated by ATP release in primary microglia. J Neurochem 2008, 107(1):152.

39. Miwa T, Furukawa S, Nakajima K, Furukawa Y, Kohsaka S: Lipopolysaccharide enhances synthesis of brain-derived neurotrophic factor in cultured rat microglia. J Neurosci Res 1997, 50(6):1023.

40. Hayashi Y, Kawaji K, Sun L, Zhang X, Koyano K, Yokoyama T, Kohsaka S, Inoue $\mathrm{K}$, Nakanishi $\mathrm{H}$ : Microglial $\mathrm{Ca}^{2+}$-activated $\mathrm{K}^{+}$channels are possible molecular targets for the analgesic effects of S-ketamine on neuropathic pain. J Neurosci 2011, 31(48):17370.

41. Saura J, Angulo E, Ejarque A, Casadó V, Tusell JM, Moratalla R, Chen JF, Schwarzschild MA, Lluis C, Franco R, Serratosa J: Adenosine $A_{2 A}$ receptor stimulation potentiates nitric oxide release by activated microglia. J Neurochem 2005, 95(4):919.

42. Brothers HM, Marchalant $Y$, Wenk GL: Caffeine attenuates lipopolysaccharide-induced neuroinflammation. Neurosci Lett 2010, 480(2):97.

43. Chen GQ, Chen YY, Wang XS, Wu SZ, Yang HM, Xu HQ, He JC, Wang XT, Chen JF, Zheng RY: Chronic caffeine treatment attenuates experimental autoimmune encephalomyelitis induced by guinea pig spinal cord homogenates in Wistar rats. Brain Res 2010, 1309:116.

44. Paternini I, Melani A, Cipriani S, Corti F, Mello T, Mazzon E, Esposito E, Bramanti P, Cuzzocrea P, Pedata F: Selective adenosine $A_{2 A}$ receptor agonists and antagonists protect against spinal cord injury through peripheral and central effects. J Neuroinflammation 2011, 8:31.

45. Assaife-Lopes N, Sousa VC, Pereira DB, Ribeiro JA, Chao MV, Sebastião AM: Activation of adenosine $A_{2 A}$ receptors induces TrkB translocation and increases BDNF-mediated phospho-TrkB localization in lipid rafts: implications for neuromodulation. J Neurosci 2010, 30(25):8468.

46. Gomes CA, Simões PF, Canas PM, Quiroz C, Sebastião AM, Ferré S, Cunha RA, Ribeiro JA: GDNF control of the glutamatergic cortico-striatal pathway requires tonic activation of adenosine $A_{2 A}$ receptors. J Neurochem 2009, 108(5):1208.

47. Gomes CA, Vaz SH, Ribeiro JA, Sebastião AM: Glial cell line-derived neurotrophic factor (GDNF) enhances dopamine release from striatal nerve endings in an adenosine $A_{2 A}$ receptor-dependent manner. Brain Res 2006, 1113(1):129.

48. Trincavelli ML, Melani A, Guidi S, Cuboni S, Cipriani S, Pedata F, Martini C: Regulation of $\mathrm{A}_{(2 \mathrm{~A})}$ adenosine receptor expression and functioning following permanent focal ischemia in rat brain. J Neurochem 2008, 104(2):479.

49. Van der Putten C, Zuiderwijk-Sick EA, van Straalen L, de Geus ED, Boven LA, Kondova I, IJzerman AP, Bajramovic JJ: Differential expression of adenosine $A_{3}$ receptors controls adenosine $A_{2 A}$ receptor-mediated inhibition of TLR responses in microglia. J Immunol 2009, 182(12):7603.

50. Yu L, Shen HY, Coelho JE, Araújo IM, Huang QY, Day YJ, Rebola N, Canas PM, Rapp EK, Ferrara J, Taylor D, Müller CE, Linden J, Cunha RA, Chen JF: Adenosine $A_{2 A}$ receptor antagonists exert motor and neuroprotective effects by distinct cellular mechanisms. Ann Neurol 2008, 63:338

51. Duan W, Gui L, Zhou Z, Liu Y, Tian H, Chen JF, Zheng J: Adenosine $A_{2 A}$ receptor deficiency exacerbates white matter lesions and cognitive deficits induced by chronic cerebral hypoperfusion in mice. J Neuro/ Sci 2009, 285(1-2):39.

52. Mayne M, Fotheringham J, Yan HJ, Power C, Del Bigio MR, Peeling J, Geiger $J D$ : Adenosine $A_{2 A}$ receptor activation reduces proinflammatory events and decreases cell death following intracerebral hemorrhage. Ann Neurol 2001, 49(6):727.

53. Cunha RA, Chen JF, Sitkovski MV: Opposite modulation of peripheral inflammation and neuroinflammation by adenosine $A_{2 A}$ receptors. In
Interaction Between Neurons and Glia in Aging and Disease. Edited by Malva JO, Rego AC, Cunha RA, Oliveira CR. Berlin: Springer-Verlag; 2007:53-79.

54. Yu L, Huang Z, Mariani J, Wang Y, Moskowitz M, Chen JF: Selective inactivation or reconstitution of adenosine $A_{2 A}$ receptors in bone marrow cells reveals their significant contribution to the development of ischemic brain injury. Nat Med 2004, 10:1081.

doi:10.1186/1742-2094-10-16

Cite this article as: Gomes et al:: Activation of microglial cells triggers a release of brain-derived neurotrophic factor (BDNF) inducing their proliferation in an adenosine $A_{2 A}$ receptor-dependent manner: $A_{2 A}$ receptor blockade prevents $B D N F$ release and proliferation of microglia. Journal of Neuroinflammation 2013 10:16.

\section{Submit your next manuscript to BioMed Central and take full advantage of:}

- Convenient online submission

- Thorough peer review

- No space constraints or color figure charges

- Immediate publication on acceptance

- Inclusion in PubMed, CAS, Scopus and Google Scholar

- Research which is freely available for redistribution 